\title{
Experimental susceptibility of Atlantic salmon Salmo salar and turbot Scophthalmus maximus to European freshwater and marine isolates of viral haemorrhagic septicaemia virus
}

\author{
J. A. King ${ }^{1, *}$, M. Snow ${ }^{1}$, H. F. Skall ${ }^{2}$, R. S. Raynard ${ }^{1}$ \\ ${ }^{1}$ FRS Marine Laboratory, PO Box 101, Victoria Road, Aberdeen AB11 9DB, Scotland, United Kingdom \\ ${ }^{2}$ Danish Veterinary Laboratory, Department of Poultry, Fish and Fur Animals, Hangøvej 2, 8200 Århus N, Denmark
}

\begin{abstract}
A number of viral haemorrhagic septicaemia (VHS) virus isolates of European marine origin were shown to be of low pathogenicity or non-pathogenic to Atlantic salmon parr by waterborne infection. A reference freshwater VHS virus isolate known to be highly pathogenic to rainbow trout was also of low pathogenicity to Atlantic salmon. Virus was detected in some mortalities, however, demonstrating viral entry and replication. European marine VHS virus isolates do not appear to pose an imminent threat to the Atlantic salmon culture industry. Turbot were found to be refractive or of low susceptibility to marine VHS virus isolates of sprat origin and to a reference freshwater isolate, with mortalities of 0 to $13.5 \%$. Conversely, turbot were susceptible by varying degrees to a number of VHS virus isolates taken from herring, with mortalities ranging from 16 to $68 \%$. These results emphasise the vulnerability of turbot culture to the VHS virus isolates that are enzootic to the European marine environment.
\end{abstract}

KEY WORDS: Viral haemorrhagic septicaemia virus · VHSV · Atlantic salmon · Turbot

\section{INTRODUCTION}

Historically, viral haemorrhagic septicaemia (VHS) is a disease of farmed rainbow trout Oncorhynchus mykiss in continental Europe. However, disease outbreaks in the marine environment have recently been recorded in cultured turbot Scophthalmus maximus in Germany (Schlotfeldt et al. 1991), Scotland (Ross et al. 1994) and Ireland (McArdle unpubl. data), and in cultured rainbow trout in Sweden (B. Nordblom unpubl. data). The occurrence of VHS virus (VHSV) in wild marine fish is becoming increasingly evident (Dixon 1999, Meyers et al. 1999, Mortensen et al. 1999). The host range appears to be broad as several marine fish species have now been reported to carry VHSV,

*E-mail: j.king@marlab.ac.uk including, from European waters, Atlantic cod Gadus morhua (Smail 1995, 2000, Mortensen et al. 1999), Atlantic herring Clupea harengus (Dixon et al. 1997, Mortensen et al. 1999), haddock Melanogramus aeglefinus (Smail 2000), Norway pout Trisopterus esmarkii, sprat Sprattus sprattus, rockling Rhinonemus cimbrius, whiting Merlangius merlangus, blue whiting Micromesistius poutassou, and lesser argentine Argentina sphyraena (Mortensen et al. 1999). The host range within the north Pacific Ocean is also growing with VHSV isolations reported from Pacific herring Clupea harengus pallasi (Meyers et al. 1994, Traxler \& Kieser 1994, Meyers \& Winton 1995, Meyers et al. 1999), Pacific cod Gadus macrocephalus (Meyers et al. 1992), chinook salmon Oncoryhnchus tshawytscha, coho salmon Oncorhynchus kisutch (Brunson et al. 1989, Hopper 1989), pilchard Sardinops sagax, blackcod Anaplopoma fimbria (Traxler et al. 1999), Pacific 
hake Merluccius productus, and walleye pollock Theragra chalcogramma (Meyers et al. 1999). The first isolation of VHSV from East Asia was recently reported from wild Japanese flounder Paralichthys olivaceus (Takano et al. 2000).

Phylogenetic analysis of nucleotide sequence data has revealed that isolates of VHSV may be grouped according to their geographic rather than their host-species origin (Benmansour et al. 1997, Stone et al. 1997, Snow et al. 1999). Indeed, analyses based on the glycoprotein gene of VHSV have identified the existence of geographically distinct genogroups of VHSV, comprising isolates from North America, continental Europe and the European marine environment (Benmansour et al. 1997, Stone et al. 1997). Further analysis of European marine isolates based on RNase protection and sequence analysis of the nucleoprotein gene has allowed subdivision of the European marine isolates into 2 groups circulating within the North (Genotype III) and Baltic Seas (Genotype II), respectively. In addition, marine isolates from the Baltic Sea were identified that were closely related to isolates from freshwater aquaculture in continental Europe (Genotype I) (Snow et al. 1999).

There is concern regarding the potential economic impact that VHS may have on the Scottish fish farming industry, particularly following the outbreak in turbot on the island of Gigha (Ross et al. 1994). Although the sources of virus in this outbreak and the turbot VHS outbreak reported in Ireland (J. McArdle unpubl. data) remain unknown, a genetic link has been identified between the isolates from these outbreaks and isolates recovered from wild fish caught around the British Isles (Stone et al. 1997, Snow et al. 1999). Thus, the virus in both the Scottish and Irish epizootics may have originated in the marine environment.

With increasing evidence of VHSV carriers among wild fish stocks, it is important to establish the susceptibility of cultivated fish to marine VHSV isolates from different marine host species. The aim of the present study was to investigate the susceptibility of Atlantic salmon to groups of marine VHSV isolates of European origin, from a range of host species. Herring and sprat have been shown to be highly prevalent carriers of VHSV in the European marine environment (Mortensen et al. 1999). Therefore, as several VHS outbreaks in turbot have already been reported, representative isolates from these 2 host species, from the genotypes identified within the European marine isolates of VHSV, were selected for investigation with regard to their infectivity to turbot.

\section{METHODS}

Fish. For Expt 1, freshwater salmon parr (mean weight $\pm \mathrm{SE}, 6.3 \pm 0.9 \mathrm{~g}$ ) and rainbow trout (mean weight $\pm \mathrm{SE}, 5.0 \pm 0.7 \mathrm{~g}$ ) were obtained from Fisheries Research Services Marine Cultivation Unit (Aultbea, Wester Ross, Scotland). For Expt 2, turbot (mean weight $\pm \mathrm{SE}, 4.4 \pm 0.9 \mathrm{~g}$ ) were obtained from Maximus A/S (Gudnæsstrandvej 17, Bedsted, Denmark). The fish were virologically tested as specific pathogen-free (12 pools of 5 fish for each species tested negative for VHSV, infectious pancreatic necrosis virus and infectious haematopoietic necrosis virus). Fish were starved for $24 \mathrm{~h}$ before infection and put into $30 \mathrm{l}$ aquaria lined with polythene bags and containing $10 \mathrm{l}$ of freshwater (activated charcoal filtered mains water) (Expt 1) or sea water (sand filtered from Nigg Bay, Aberdeen) (Expt 2), with aeration. Triplicate tanks each holding 40 (Expt 1) or 35 (Expt 2) fish were set up for each test group.

VHSV propagation. Stocks of virus were grown on the bluegill fry caudal trunk cell line (BF-2, pass number 3 to 6) cultivated in either Eagle's minimum essential medium (Gibco BRL, Life Technologies, UK) or Glasgow minimum essential medium (GMEM, Gibco), plus $10 \%$ foetal bovine serum (Sigma-Aldrich Co. Ltd,

Table 1. Expt 1. Groups of viral haemorrhagic septicaemia (VHS) virus isolates for infection of Atlantic salmon (groups 1 to 11), with origin of virus isolation. Control groups for Atlantic salmon (groups 14 and 15) and reference rainbow trout (groups 12 and 13) infected with DK-3592B (positive control) or Glasgow minimum essential medium-10 (negative control)

\begin{tabular}{|lccl|}
\hline Group & VHS virus isolates & Host species & Source \\
\hline 1 & $1 \mathrm{p} 49,1 \mathrm{p} 53,1 \mathrm{p} 64,1 \mathrm{p} 85,1 \mathrm{p} 120$ & Herring & Mortensen et al. (1999) \\
2 & $1 \mathrm{p} 3,1 \mathrm{p} 8,1 \mathrm{p} 12,1 \mathrm{p} 110,1 \mathrm{p} 125$ & Herring & Mortensen et al. (1999) \\
3 & $1 \mathrm{p} 52,1 \mathrm{p} 55,1 \mathrm{p} 86,1 \mathrm{p} 121$ & Sprat & Mortensen et al. (1999) \\
4 & $1 \mathrm{p} 50,1 \mathrm{p} 111,1 \mathrm{p} 124,1 \mathrm{p} 128$ & Sprat & Mortensen et al. (1999) \\
5 & $1 \mathrm{p} 54,1 \mathrm{p} 93$ & Cod & Mortensen et al. (1999) \\
6 & $1 \mathrm{e} 62,1 \mathrm{p} 109,1 \mathrm{p} 116$ & Cod & Mortensen et al. (1999) \\
7 & H17/5/93, H19/1/93, H16/7/95 & Cod & Smail (1995, 2000) \\
8 & H17/1/95, H17/2/95 & Haddock & Smail (2000) \\
9 & $860 / 94$ & Turbot & Ross et al. (1994) \\
10 & $1 \mathrm{p} 40,2 \mathrm{p} 51,4 \mathrm{p} 51$ & Rockling, Norway & Mortensen et al. (1999) \\
& & pout, lesser Argentine & \\
11 & $4 \mathrm{p} 37,4 \mathrm{p} 101$ & Blue whiting, & Mortensen et al. (1999) \\
& & whiting & \\
12 & DK-3592B & Rainbow trout & Lorenzen et al. (1990) \\
13 & Negative control & - & - \\
14 & DK-3592B & Rainbow trout & Lorenzen et al. (1990) \\
& Negative control & - & - \\
\hline
\end{tabular}


UK) (GMEM-10). Each virus was diluted in GMEM-10 to give a final dose of $10^{9}$ TCID $_{50}$ isolate $^{-1}$ to be added to each tank, giving a final dose of $10^{5} \mathrm{TCID}_{50} \mathrm{ml}^{-1}$ isolate $^{-1}$ in a volume of 10 l. Negative control groups received GMEM-10 alone.

Expt 1. VHSV infection of Atlantic salmon. To test a large number of VHSV isolates, Atlantic salmon were experimentally infected with groups of from 1 to 5 marine isolates originating from the same host species, as shown in Table 1. It has previously been shown with waterborne infection studies on salmonids that simultaneous exposure to more than $1 \mathrm{VHSV}$ isolate does not compromise the virulence of individual isolates (Skall unpubl. data). Isolates within a group were diluted and mixed to obtain a final dose of $10^{5} \mathrm{TCID}_{50} \mathrm{ml}^{-1}$ isolate ${ }^{-1}$. Positive and negative control groups were included using rainbow trout as the reference species known to be susceptible to a freshwater VHSV isolate (DK-3592B, Lorenzen et al. 1990).

Expt 2. VHSV infection of turbot. Turbot were experimentally infected with 4 individual virus isolates from sprat and 5 individual isolates from herring (Table 2). The turbot isolate 860/94 originating from a farm outbreak at Gigha, West Scotland (Ross et al. 1994), was used as a positive control for the infection protocol. The freshwater rainbow trout isolate DK3592B was also tested along with a negative control group.

Infection protocol. The virus solutions were poured into triplicate tanks for each group and thoroughly mixed. The polythene bags were tied to contain aerosols and reduce the risk of cross-contamination between tanks. Following a $6 \mathrm{~h}$ exposure to the virus, the fish were gently tipped out of the bags into the tanks. The water volume was raised to $30 \mathrm{l}$ and water flow rates were set to $50 \mathrm{l} \mathrm{h}^{-1}$. The water temperature was maintained at $10 \pm 1^{\circ} \mathrm{C}$ and aeration was provided for the duration of the experiment. The photoperiod was set for $12 \mathrm{~h}$ of daylight and the fish were fed a commercial pellet diet.

Fish were checked daily, and dead fish were removed and either sampled immediately for spleen and kidney (pooled) and brain (Expt 2 only) or stored whole at $-80^{\circ} \mathrm{C}$ and sampled at a later date. The experiments were terminated on Days 55 (Expt 1) and 61 (Expt 2) post-infection.

Virus recovery and confirmation. Fish mortalities were tested for VHSV recovery to fulfill Rivers' postulates (Rivers 1937) and show that death was due to
VHSV. Tissue samples were weighed and homogenised in microcentrifuge tubes using pellet pestles (Anachem Ltd, UK). The homogenate was resuspended in 9 volumes of transport medium (GMEM-10, $2 \mathrm{mM}$ L-glutamine, $50 \mu \mathrm{g} \mathrm{ml}^{-1}$ gentamycin, $100 \mathrm{U} \mathrm{ml}^{-1}$ polymixin-B, $2.5 \mu \mathrm{g} \mathrm{ml^{-1 }}$ fungizone; Gibco) and centrifuged at $1000 \times g$ for $20 \mathrm{~min}$ at $4^{\circ} \mathrm{C}$. BF-2 cells were seeded onto 24-well tissue culture plates (Nunc Life Technologies, UK) to reach a confluency of 60 to $70 \%$ after $24 \mathrm{~h}$ in $900 \mu \mathrm{l}$ GMEM-10 well $^{-1}$. Tissue homogenates were added to the cell cultures and serially diluted to give final dilutions of 1:100, 1:1000 and 1:10000. The inoculated tissue culture plates were incubated at $15^{\circ} \mathrm{C}$ and monitored for viral cytopathic effect (CPE). After $7 \mathrm{~d}$ incubation, samples not showing evidence of CPE were passaged to fresh $24 \mathrm{~h}$ BF-2 seeded 24-well tissue culture plates by pooling supernatants from each of the 3 dilution wells of the primary plate and serially diluting to give final dilutions of 1:10 and 1:100. The plates were incubated at $15^{\circ} \mathrm{C}$ and monitored for CPE.

Cell cultures showing evidence of CPE were tested by ELISA using a commercial diagnostic kit according to the manufacturer's instructions (Test-Line Limited Clinical Diagnostics, Brno, Czech Republic) to confirm the presence of VHSV. Medium from each CPE-positive well was centrifuged at $30000 \times g$ for $10 \mathrm{~min}$ at $4^{\circ} \mathrm{C}$ to remove cell debris. The resulting supernatant was added to a microtitre plate precoated with purified polyclonal anti-VHSV antibody. Positive and negative controls and blanks supplied in the kit were also added. VHSV was detected by the binding of rabbit anti-VHSV antibody, followed by peroxidase-labelled antibody to rabbit immunoglobulin and finally the chromogenic substrate, tetramethyl-benzidine. 
Table 3. Expt 1. VHS virus infection of Atlantic salmon. Mean percentage mortality of Atlantic salmon test infections (Groups 1 to 11), positive control (Group 14) and negative control (Group 15), reference rainbow trout positive control (Group 12) and negative control (Group 13), 32 d postinfection with $\mathrm{SE}, \mathrm{n}=3$. Summary of mortality testing for VHS virus recovery with the number of kidney and spleen (organ) samples positive for VHS virus of the total number tested (expressed as a percentage)

\begin{tabular}{|c|c|c|c|}
\hline \multirow[t]{2}{*}{ Group } & \multicolumn{2}{|c|}{ Mortality (\%) } & \multirow{2}{*}{$\begin{array}{l}\text { No. of organ samples positive/ } \\
\text { total number tested for VHS virus }\end{array}$} \\
\hline & Mean & SE & \\
\hline 1 & 2.5 & 0 & $2 / 3(66.7 \%)$ \\
\hline 2 & 3.3 & 0.8 & $0 / 3(0 \%)$ \\
\hline 3 & 0 & 0 & - \\
\hline 4 & 0 & 0 & - \\
\hline 5 & 0.8 & 0.8 & $0 / 1(0 \%)$ \\
\hline 6 & 0 & 0 & - \\
\hline 7 & 0.8 & 0.8 & $0 / 1(0 \%)$ \\
\hline 8 & 2.5 & 1.4 & $0 / 3(0 \%)$ \\
\hline 9 & 0 & 0 & - \\
\hline 10 & 0 & 0 & - \\
\hline 11 & 2.5 & 2.5 & $0 / 2(0 \%)$ \\
\hline 12 & 89.2 & 4.4 & 29 / $30(96.7 \%)$ \\
\hline 13 & 0 & 0 & - \\
\hline 14 & 1.7 & 0.8 & $1 / 2(50 \%)$ \\
\hline 15 & 1.7 & 1.7 & $0 / 2(0 \%)$ \\
\hline
\end{tabular}

\section{RESULTS}

\section{Expt 1. VHSV infection of Atlantic salmon}

At 32 d post-infection, mortalities of only 0 to $3.3 \%$ had occurred in the Atlantic salmon test and control groups (Table 3). As groups of 2 or more VHSV isolates were tested in some cases, it was not possible to determine which isolate, or isolates, within the group had caused mortality in Groups 1, 2, 5, 7, 8 and 11. None of the Atlantic salmon mortalities showed typical gross pathology for VHS. The rainbow trout positive controls (Group 12) achieved a high mortality rate $(89.2 \pm 4.4 \%$, mean $\pm \mathrm{SE}, \mathrm{n}=$ $3)$, and there were no mortalities in the negative controls (Group 13).

Mortalities were individually tested for VHSV isolation from samples of kidney and spleen (pooled organs) (Table 3). VHSV was recovered from $96.7 \%$ of the fish tested from the rainbow trout positive controls (Group 12). One of the 2 fish mortalities from the Atlantic salmon positive controls (Group 14) was VHSV positive; virus was not detected from either of the 2 mortalities from the negative controls
(Group 15). Of the salmon test groups, VHSV was recovered only from mortalities from Group 1 (66.7\%). All others tested negative for virus recovery. Surviving fish were not tested for virus.

\section{Expt 2. VHSV infection of turbot}

The mortality results for each group are summarised in Table 4. A high level of mortality was achieved with the positive control group (66.3\%, Group 11) and the mortality rate in the negative control group was zero, therefore validating the infection protocol.

Mortalities were observed in all groups that were infected with the herring isolates (Groups 6-10), ranging from low level mortality of $16.5 \%$ in Group 6 to high level mortality of $68.6 \%$ in Group 10, which was comparable with that of the positive control group. However, the mortality rate was significant in only 1 (Group 5) of the groups infected with the sprat isolates (Groups 2 to 5), although this was of a low level at $13.5 \%$. A negligible mortality rate was recorded in fish infected with the freshwater reference isolate DK-3592B (Group 12). In the high virulence groups (Groups 10 and 11), mortality was first recorded at around $14 \mathrm{~d}$ post-infection $(14.2 \pm 0.7 \mathrm{~d}$, mean $\pm \mathrm{SE}, \mathrm{n}=$ $6)$ whereas, in low virulence groups (Groups 5 and 6), mortality tended to occur later, at $25 \mathrm{~d}$ post-infection $(24.7 \pm 2.6 \mathrm{~d}$, mean $\pm \mathrm{SE} \mathrm{n}=6)$. Dead fish showed reported pathology for VHS, including darkening of the body, haemorrhaging of the head and the fins, and ascitic fluid in the body cavity (Castric \& de Kinkelin 1984) (Fig. 1).
Table 4. Expt 2. VHS virus infection of turbot. Mean percentage mortality of turbot test infections (Groups 2 to 10), negative control (Group 1), positive control (group 11) and reference freshwater isolate (Group 12), $61 \mathrm{~d}$ post-infection with $\mathrm{SE}, \mathrm{n}=3$. Summary of mortality testing for VHS virus recovery with the number of kidney and spleen (organ) samples and brain samples positive for VHS virus of the total numbers tested (expressed as a percentage)

\begin{tabular}{|lcccc|}
\hline Group & $\begin{array}{c}\text { Mortality (\%) } \\
\text { Mean }\end{array}$ & $\begin{array}{c}\text { Ne. of organ samples } \\
\text { positive/total number } \\
\text { tested for VHS virus }\end{array}$ & $\begin{array}{c}\text { No. of brain samples } \\
\text { positive/total number } \\
\text { tested for VHS vius }\end{array}$ \\
\hline 1 & 0 & 0 & - & - \\
2 & 0 & 0 & - & - \\
3 & 0.9 & 0.9 & $1 / 1(100 \%)$ & $1 / 1(100 \%)$ \\
4 & 0.9 & 0.9 & $1 / 1(100 \%)$ & $1 / 1(100 \%)$ \\
5 & 13.5 & 2.6 & $11 / 12(91.7 \%)$ & $11 / 12(91.7 \%)$ \\
6 & 16.5 & 6.9 & $8 / 14(57.1 \%)$ & $9 / 14(64.3 \%)$ \\
7 & 37.4 & 0.2 & $17 / 26(65.4 \%)$ & $17 / 26(65.4 \%)$ \\
8 & 27.9 & 2.6 & $10 / 21(47.6 \%)$ & $11 / 21(52.4 \%)$ \\
9 & 39 & 6.2 & $15 / 26(57.7 \%)$ & $18 / 26(69.2 \%)$ \\
10 & 68.6 & 8.7 & $30 / 36(83.3 \%)$ & $31 / 36(86.1 \%)$ \\
11 & 66.3 & 1.8 & $33 / 35(94.3 \%)$ & $32 / 35(91.4 \%)$ \\
12 & 2.9 & 1.7 & $0 / 3(0 \%)$ & $2 / 3(66.7 \%)$ \\
\hline
\end{tabular}



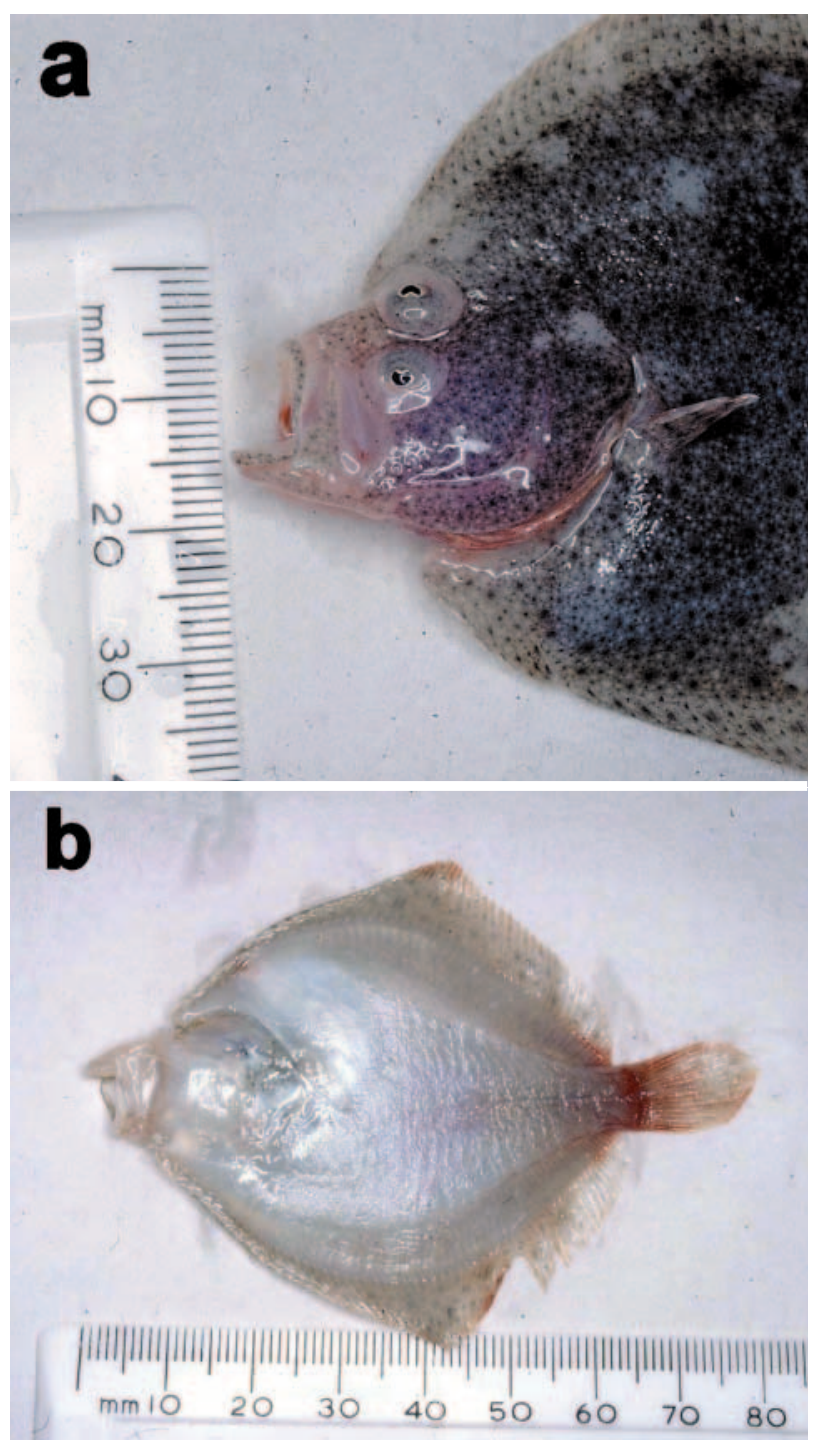

Fig 1. Turbot infected with isolate 860/94 exhibiting gross pathology of viral haemorrhagic septicaemia. (a) Haemorrhaging of the head; (b) haemorrhaging of the fins

A generalised linear regression analysis of the mortality data (Genstat 5, Release 3 computer software) showed that mortality in Groups 10 and 11 was significantly higher than in the other groups $(\mathrm{p}<0.001$; Groups 1 and 2 were not included as the mortality rate was zero).

Sub-samples of the mortalities from each group were individually tested for VHSV isolation from samples of kidney and spleen (pooled) and brain. The sample sizes required to estimate the proportion of mortalities that were due to VHSV were determined at the $95 \%$ confidence level using the method of Thompson (1992). This method was based on the assumption that at least $50 \%$ of mortalities were due to VHSV infection with an acceptable error difference of $10 \%$. The results are shown in Table 4. Of the mortalities tested from the positive control group infected with the Gigha turbot isolate (Group 11), $94 \%$ of organ samples and $91 \%$ of brain samples were positive for VHSV. Isolation of VHSV from mortalities infected with isolates from sprat (Groups 3, 4 and 5) was consistently high at $91 \%$ to $100 \%$. However, isolation from mortalities infected with virus isolates from herring varied from $47 \%$ (Group 8, organs) up to $86 \%$ (Group 10, brains). The isolation rate from brain tissue was comparable with that from kidney and spleen pools in all groups, with the exception of Group 12, the freshwater reference isolate (DK-3592B), where VHSV was isolated only from brain, and not from kidney and spleen.

\section{DISCUSSION}

Atlantic salmon parr were not susceptible to groups of marine VHSV isolates from a range of host species nor to a reference freshwater isolate. However, virus detection in some mortalities demonstrated that viral entry and replication can occur. Virus has been recovered from Atlantic salmon fry exposed by immersion to the VHSV freshwater reference isolates 07/71 and $23 / 75$, with good levels of neutralising activity in the serum being detected (de Kinkelin \& Castric 1982). Infection trials with rainbow trout fingerlings showed that VHSV isolates from wild marine fish species, including all those isolates tested during this study, were non-pathogenic by immersion (Skall unpubl. data). Similarly, pathogenicity tests have shown the North American strains of VHSV to be of relatively low pathogenicity to salmonids (Follett et al. 1997, Meyers \& Winton 1995, Traxler et al. 1995). Indeed, injection and bath exposure of Atlantic salmon to a North American marine strain caused losses only in the virusinjected fish and virus was not recovered from fish exposed by immersion (Traxler et al. 1999).

Turbot appeared to be very resistant to the freshwater VHSV isolate DK-3592B, with only $3 \%$ mortality. However, the susceptibility of turbot to other VHSV isolates of European freshwater origin has been shown previously. Waterborne challenge and intra-peritoneal injection with reference freshwater isolates 07/71 and $23 / 75$ resulted in $24 \%$ and over $90 \%$ mortality, respectively (Castric \& de Kinkelin 1984). This suggests that VHSV isolates of freshwater origin may have substantial variability in virulence for turbot.

Turbot were shown to be very susceptible to the turbot VHSV isolate 860/94 from Gigha with $66 \%$ mortality. Similarly, another study investigating the virulence of the Gigha marine isolate to turbot showed $71 \%$ mortality by immersion challenge and $100 \%$ mortality by 
intra-peritoneal challenge, with horizontal transmission of VHSV in sea water being shown by $60 \%$ mortality of cohabiting fish (Snow \& Smail 1999).

Turbot were found to be susceptible by varying degrees to all the VHSV isolates tested that originated from herring, with mortalities from 16.5 to $68.6 \%$, but the isolates from sprat were not virulent or of low virulence ( 0 to $13.5 \%$ mortality). The isolation of virus from brain tissue, as well as kidney and spleen, shows evidence for the neural form of the disease, which has been found previously (Snow \& Smail 1999). These results suggest that there is a variability in the virulence for turbot of marine VHSV isolates from different host species and also between different isolates from within the same host species.

There is some evidence that the virulence of marine VHSV isolates for turbot is dependent on the geographic origin rather than the host species of each isolate. Indeed, isolates 860/94 (turbot host) and 4p168 (herring host) recovered from waters within the British Isles and the Skagerrak, respectively (genotype III; Snow et al. 1999), produced the highest mortality rates in turbot. This evidence, coupled to the genetic link established between isolate 860/94 and other isolates recovered from around the British Isles (Stone et al. 1997, Snow et al. 1999), further supports the possibility that the origin of isolate 860/94 was the marine environment. Whether the epizootic in turbot at Gigha resulted from the horizontal transmission of virus from wild fish species in the immediate vicinity of the turbot farm at Gigha or from the import of virus in unpasteurised fish product used at the site remains unclear.

The remaining isolates tested against turbot, all originating from the Baltic Sea, resulted in lower mortality rates, ranging from 0 to $39 \%$. Isolates 1 p5 2 and 1 p55 (sprat host), which are representatives of genotype II (Snow et al. 1999), both caused very low mortality in turbot. The other isolates, also from the Baltic Sea but more closely related to isolates from continental Europe (genotype I; Snow et al. 1999), generally resulted in intermediate mortalities ranging from 13.5 to $39 \%$; the only exception was isolate 1 p86 (sprat host). As the separation of isolates into these genotypes was based on a short region of the N-gene of VHSV, such exceptions are perhaps not surprising. Indeed, the N-gene codes for an internal protein that is generally well conserved and thus unlikely to be a direct determinant of pathogenicity.

The risk of VHS to the Atlantic salmon culture industry in Europe appears to be low. Indeed, after many years of rigorous testing, no VHSV has ever been isolated from Atlantic salmon in Scotland. However, the North American strain of VHSV has been isolated from farmed Atlantic salmon in Canada (Traxler et al. 1995). Hence, the evidence does not preclude the potential for a VHSV strain that is virulent for Atlantic salmon to emerge in Europe, but our data together with other published reports lead to the conclusion that Atlantic salmon are not at direct risk from VHSV. The results of this study indicate that turbot are susceptible to a number of VHSV isolates that are enzootic to the European marine environment and that protection against this disease, therefore, is a necessary consideration for the future of turbot culture.

Acknowledgements. Thanks go to the Aquarium Services group at FRS Marine Laboratory Aberdeen for their assistance in aquarium sampling and to the staff at the Marine Cultivation Unit, Aultbea for supplying fish. This work was carried out under the EC project Rhabdoviruses in Wild Marine Fish in European Coastal Waters: Characterisation and Significance for Aquaculture, FAIR CT 96.1594.

\section{LITERATURE CITED}

Benmansour A, Basurco B, Monnier AF, Vende P, Winton J, de Kinkelin P (1997) Sequence variation of the glycoprotein gene identifies three distinct lineages within field isolates of viral haemorrhagic septicaemia virus, a fish rhabdovirus. J Gen Virol 78:2837-2846

Brunson R, True K, Yancey J (1989) VHS virus isolated at Makah National Fish Hatchery. Am Fish Soc Fish Health Newsl 17:3

Castric J, de Kinkelin P (1984) Experimental study of the susceptibility of two marine fish species, sea bass (Dicentrarchus labrax) and turbot (Scophthalmus maximus), to viral haemorrhagic septicaemia. Aqua 41:203-212

de Kinkelin P, Castric J (1982) An experimental study of the susceptibility of Atlantic salmon fry, Salmo salar L., to viral haemorrhagic septicaemia. J Fish Dis 5:57-65

Dixon PF (1999) VHSV came from the marine environment: clues from the literature, or just red herrings? Bull Eur Assoc Fish Pathol 19:60-65

Dixon PF, Feist S, Kehoe E, Parry L, Stone DM, Way K (1997) Isolation of viral haemorrhagic septicaemia virus from Atlantic herring Clupea harengus from the English Channel. Dis Aquat Org 30:81-89

Follett JE, Meyers TR, Burton TO, Geesin JL (1997) Comparative susceptibilites of salmonid species in Alaska to infectious haematopoietic necrosis virus (IHNV) and North American viral haemorrhagic septicaemia virus (VHSV). J Aquat Anim Health 9:34-40

Hopper K (1989) The isolation of VHSV from chinook salmon at Glenwood Springs, Orcas Island, Washington. Fish Health Sect Am Fish Soc Newsl 17:1-2

Lorenzen N, Olesen NJ, Jørgensen PEV (1990) Neutralization of Egtved virus pathogenicity to cell cultures and fish monoclonal antibodies to the viral G-protein. J Virol 71: 733-738

Meyers TR, Winton JR (1995) Viral haemorrhagic septicaemia virus in North America. Annu Rev Fish Dis 5:3-24

Meyers TR, Sullivan J, Emmenegger E, Follett J, Short S, Batts WN, Winton JR (1992) Identification of viral haemorrhagic septicaemia virus isolated from Pacific cod Gadus macrocephalus in Prince William Sound, Alaska, USA. Dis Aquat Org 12:167-175

Meyers TR, Short S, Lipson K, Batts WN, Winton JR, Wilcock J, Brown E (1994) Association of viral haemorrhagic septi- 
caemia virus with epizootic haemorrhages of the skin in Pacific herring Clupea harengus pallasi from Prince William Sound and Kodiak Island, Alaska, USA. Dis Aquat Org 19:27-37

Meyers TR, Short S, Lipson K (1999) Isolation of the North American strain of viral haemorrhagic septicaemia virus (VHSV) associated with epizootic mortality in two new host species of Alaskan marine fish. Dis Aquat Org 38: 81-86

Mortensen HF, Heuer OE, Lorenzen N, Otte L, Olesen NJ (1999) Isolation of viral haemorrhagic septicaemia virus from wild marine fish species in the Baltic Sea, Kattegat, Skagerrak and the North Sea. Virus Res 63:95-106

Rivers TM (1937) Viruses and Koch's postulates. J Bacteriol 33:1-12

Ross K, McCarthy U, Huntly PJ, Wood BP, Stuart D, Rough EI, Smail DA, Bruno DW (1994) An outbreak of viral haemorrhagic septicaemia (VHS) in turbot (Scophthalmus maximus) in Scotland. Bull Eur Assoc Fish Pathol 14:213-214

Schlotfeldt HJ, Ahne W, Vestergard Jørgensen PE, Glende W (1991) Occurrence of viral haemorrhagic septicaemia in turbot (Scophthalmus maximus): a natural outbreak. Bull Eur Assoc Fish Pathol 11:105-107

Smail DA (1995) Isolation and identification of viral haemorrhagic septicaemia (VHS) virus from North Sea cod (Gadus morhua L.). ICES Maricult Comm CM 1995/F:15

Smail DA (2000) Isolation and identification of viral haemorrhagic septicaemia (VHS) viruses from cod Gadus morhua with the ulcus syndrome and from haddock Melanogrammus aeglefinus having skin haemorrhages in the North Sea. Dis Aquat Org 41:231-235

Editorial responsibility: Jo-Ann Leong,

Corvallis, Oregon, USA
Snow M, Smail DA (1999) Experimental susceptibility of turbot Scophthalmus maximus to viral haemorrhagic septicaemia virus isolated from cultivated turbot. Dis Aquat Org 38:163-168

Snow M, Cunningham CO, Melvin WT, Kurath G (1999) Analysis of the nucleoprotein gene identifies distinct lineages of viral haemorrhagic septicaemia virus within the European marine environment. Virus Res 63:35-44

Stone DM, Way K, Dixon PF (1997) Nucleotide sequence of the glycoprotein gene of viral haemorrhagic septicaemia (VHS) viruses from different geographical areas: a link between VHS in farmed fish species and viruses isolated from North Sea cod (Gadus morhua L.). J Gen Virol 78: $1319-1326$

Takano R, Nishizawa T, Arimoto M, Muroga K (2000) Isolation of viral haemorrhagic septicaemia virus (VHSV) from wild Japanese flounder, Paralichthys olivaceus. Bull Eur Assoc Fish Pathol 20:186-192

Thompson S (1992) Sampling. Wiley series in probability and mathematical statistics. John Wiley and Sons, New York

Traxler GS, Kieser D (1994) Isolation of the North American strain of viral haemorrhagic septicaemia virus (VHSV) from herring (Clupea harengus pallasi) in British Columbia. Fish Health Sect Am Fish Soc Newsl 22:8

Traxler GS, Kieser D, Evelyn TPT (1995) Isolation of North American strain of VHS virus from farmed Atlantic salmon. Aquacult Update 72:1-2

Traxler GS, Kieser D, Richard J (1999) Mass mortality of pilchard and herring associated with viral haemorrhagic septicaemia virus in British Columbia, Canada. Fish Health Sect Am Fish Soc Newsl 27:3-4

Submitted: February 22, 2001; Accepted: June 19, 2001

Proofs received from author(s): October 15, 2001 